\title{
Combination of factors for the presence of the public: a look at the lower levels of football in Minas Gerais
}

\author{
Combinação de fatores para a presença do público: um olhar para os níveis mais baixos do futebol \\ mineiro
}

\section{Combinación de factores para la presencia del público: una mirada a los niveles más bajos del fútbol en Minas Gerais}

\author{
Felipe Alexandre de Souza Félix Nunes ${ }^{1}$ iD, Jonathan Simões Freitas ${ }^{1}$ (iD
}

Universidade Federal de Minas Gerais - UFMG ${ }^{1}$ - fasfn@adm.mest.ufmg.br

\begin{abstract}
At the lowest levels of football in Brazil, one of the revenue sources is the box office leading to the need to identify the motivations of fans to attend stadiums and support their favorite football teams. The occupancy rate of Brazilian stadiums is lower than in other competitions in the world, which denotes the importance of knowing the configurations that mobilize the presence of the fans in following the matches. Brazil has more than 850 professional football clubs and only 128 of these teams compete in one of the four divisions of the national championship and studies point to the importance of regional championships in the Brazilian football ecosystem. This work aimed to analyze comparatively the matches of the first professional divisions, divided into 291 matches of Module I and 332 matches of Module II, of the Campeonato Mineiro, the Minas Gerais state championship, between 2015 and 2018 seeking to understand in which combinations of factors the public is present in the stadiums. This research found a combination of factors using Coincidence Analysis that implies the importance of high-ranking teams, acting in matches as a visitor, in attracting the public to stadiums to watch Module I of the Minas Gerais Soccer Championship. It also found minimally sufficient conditions that showed the importance of the rivalry factor and performance-related factors in causing a good occupancy rate of Module II of the state championship. This study brings notes to the importance of high-ranking teams in the dispute, necessary to attract the public to the stadiums in the games of Module I of the state championship of Minas Gerais. It also expands the scenario that covers most professional clubs in Brazil and is distant from the eyes of the great public fan of the sport.
\end{abstract}

Keywords: Football; Match Day Revenues; Coincidence Analysis; State Championship.

\section{Resumo}

Nos níveis mais baixos do futebol no Brasil, uma das fontes de receita é a bilheteria o que leva à necessidade de identificar as motivações dos torcedores para ir aos estádios e apoiar seus times de futebol favoritos. A taxa de ocupação dos estádios brasileiros é menor do que em outras competições do mundo, o que denota a importância de se conhecer as configurações que mobilizam a presença da torcida no acompanhamento das partidas. O Brasil possui mais de 850 clubes de futebol profissional e apenas 128 desses times disputam uma das quatro divisões do campeonato nacional e estudos apontam para a importância dos campeonatos regionais no ecossistema do futebol brasileiro. Portanto, para esses campeonatos, é um desafio atrair o público para assistir aos jogos no estádio. Este trabalho teve como objetivo analisar comparativamente as partidas das primeiras divisões profissionais, divididos em 291 jogos do Módulo I e 332 jogos do Módulo II, do Campeonato Mineiro entre 2015 e 2018, buscando compreender em quais combinações de fatores o público está presente nos estádios. Esta pesquisa encontrou uma combinação de fatores por meio da Análise de Coincidência que implica na importância das equipes de alto escalão, atuando em partidas como visitante, na atração do público aos estádios para assistir ao Módulo I do Campeonato Mineiro de Futebol. Também encontrou condições minimamente suficientes que mostraram a importância do fator rivalidade e fatores relacionados ao desempenho na causa de uma boa taxa de ocupação do estádio do Módulo II do campeonato estadual. Este estudo traz apontamentos que tornam as equipes de alto escalão fatores necessários para atrair 
público nos campeonatos do Módulo I do campeonato estadual de Minas Gerais. Também amplia o cenário que abrange a maioria dos clubes profissionais do Brasil e está distante dos olhos do grande público adepto do esporte.

Palavras-chave: Futebol; Receitas do dia do jogo; Análise de Coincidência; Campeonato Estadual.

\section{Resumén}

En los niveles más bajos del fútbol en Brasil, una de las fuentes de ingresos es la taquilla, lo que lleva a la necesidad de identificar las motivaciones de los fanáticos para asistir a los estadios y apoyar a sus equipos de fútbol favoritos. La tasa de ocupación de los estadios brasileños es menor que en otras competiciones del mundo, lo que denota la importancia de conocer las configuraciones que movilizan la presencia de la afición en el seguimiento de los partidos. Brasil tiene más de 850 clubes de fútbol profesional y solo 128 de estos equipos compiten en una de las cuatro divisiones del campeonato nacional y los estudios apuntan a la importancia de los campeonatos regionales en el ecosistema del fútbol brasileño. Este trabajo tuvo como objetivo analizar comparativamente los partidos de las primeras divisiones profesionales, divididos en 291 partidos del Módulo I y 332 partidos del Módulo II, del Campeonato Mineiro, el campeonato estatal de Minas Gerais, entre 2015 y 2018 buscando entender en qué combinaciones de factores el público está presente en los estadios. Esta investigación encontró una combinación de factores utilizando el Análisis de Coincidencia que implica la importancia de los equipos de altos niveles, que actúan en los partidos como visitantes, para atraer al público a los estadios para ver el Módulo I del Campeonato de Fútbol de Minas Gerais. También encontró condiciones mínimamente suficientes que mostraron la importancia del factor de rivalidad y los factores relacionados con el desempeño para causar una buena tasa de ocupación del Módulo II del campeonato estatal. Este estudio señala la importancia de los equipos de alto nivel en la disputa, necesarios para atraer al público a los estadios en los juegos del Módulo I del campeonato estatal de Minas Gerais. También amplía el escenario que cubre la mayoría de los clubes profesionales de Brasil y se aleja de la mirada del gran público aficionado al deporte.

Palabras Clabe: Fútbol; Ingresos del día del partido; Análisis de coincidencia; Campeonato estatal.

\section{Introduction}

Recent studies in the Marketing area have sought to identify the motivations of fans to attend stadiums and support their favorite football teams (Fagundes et al., 2013; Gasparetto et al., 2018). The structure of Brazilian football consists of four main divisions of the national championship organized by the Brazilian Football Confederation (CBF) and other state professional championships, 27 in total, just like the number of states in the country and each organized by their respective football federation (Serrano, 2018).

A recent study showed that there are more than 28 thousand professional soccer players registered in Brazil, with the vast majority (82.4\%) receiving monthly salaries close to the national minimum wage $\left(€ 178,13^{1}\right)(\mathrm{CBF}, 2019)$. This great mass of athletes acts, mainly, in the state championships which, although they are not as prestigious as they were in the past, they still work as showcases for foreign markets, such as the negotiation of striker Gabriel Martinelli who played in a state championship and was negotiated directly with Arsenal (Penn, 2019). At these levels, revenue sources vary from deals for the economic rights of players, investors, sponsorship, public funds, and box office (Silveira \& Melo, 2018).

Although these tournaments are fundamental to the working ecosystem of Brazilian football, a portion of the Brazilian sports press calls for a significant change in the format of these tournaments. For example, Mauro Cezar Pereira (2014), a Brazilian journalist who has over 1 million Twitter followers, "I do not defend the end of the state's championships, but their total reformulation".

\footnotetext{
${ }^{1}$ Using the exchange rate from Brazilian Reais to Euros for 1 Euro equal to 6.178 Brazilian Reais. Available in <https://economia.uol.com.br/cotacoes/cambio/euro-uniao-europeia/>. Accessed in: August 27, 2021.
} 
Another reference in the Brazilian sports media, Paulo Vinícius Coelho (2020) says, "The state's championships as we know them ended today".

An important metric to guide a change in the format of competitions is to understand what reasons are necessary to attract the public to the stadiums to follow a match of these levels. The purpose of this work was to analyze matches from the two highest levels of the championship of the state of Minas Gerais, Module I and Module II, to point out necessary and sufficient factors for the presence of the public in the stadiums between 2015 and 2018. This work aims to understand the combinations of factors that cause the public to go to the stadiums to follow the games of these championships.

The justifications for this study are in two pillars. Partly because the basis of the structure of football in Brazil, in relation to the number of professional players, is in the state championships competitions that no longer boast the prestige that existed in the first years of professional football in Brazil. Another foundation to justify this research is the lack of empirical observations from even lower levels of football, in this work, for example, Module II of the Campeonato Mineiro (Minas Gerais State Championship).

\section{Literature review}

The occupancy rate of Brazilian stadiums is lower than in other competitions in the world, such as the Major League Soccer (MLS) or the Bundesliga (Rocha \& Fleury, 2017), which denotes the importance of knowing the configurations that mobilize the presence of the fans in following the matches. The complex behavior of these industry spectators is due to the demands and objectives of the various factors involved.

Brazil has more than 850 professional football clubs and only 128 of these teams compete in one of the four divisions of the national championship. There are also state championships in all 27 units of the Brazilian federation, with the second division in 26 of those states. A few states still have a third division and others have a fourth and fifth division of the state championship (CBF, 2019). The football clubs in the state of Minas Gerais, which are active, are divided into three levels: Module I, Module II and the so-called Segunda Divisão (Second Division), which in practice is equivalent to the third category.

Between 2015 and 2017, Module I was played in a first stage with 12 teams playing for 11 rounds, and then the four best-placed teams faced other two phases, semifinals, and finals, in two matches each. In 2018 eight of 12 teams were qualified for a single quarterfinal match, and then semifinals and finals in two matches. Module II was played in two different formats. In the years 2015, 2016, and 2017 the teams played for 10 rounds and then the six best-placed teams faced each other in two rounds in a hexagonal of 10 more rounds. In 2018, 11 rounds were played and the best four went on to a semi-final and final playoff with two matches in each of these stages.

Studies like Serrano (2018) and Gasparetto et al. (2018) point to the importance of regional championships in the Brazilian football ecosystem. Although they are important, these tournaments face a decline in prestige with the public. The work of Silveira and Melo (2018) shows the difficulties faced by clubs in the lower divisions in generating income to guarantee the subsistence of these organizations. Among the origins of the resources are the sale of tickets, related products, public resources, and local sponsorship. Therefore, for these championships, there is the challenge to attract the public to watch the games in the stadium. 
The literature points to factors as possible contributors to attendance in a match more than in others. A technical report on factors that attract the public to stadiums in editions of the Brazilian Championship between 2012 and 2017 showed that the good classification of the home team is an important element in attracting the public, whether at the beginning or the end of the competition (ADMKT, 2018). In another study from the beginning of the last decade about the Brazilian Championship, factors such as a cheaper average ticket and the performance of the main team were considered relevant in the presence of the public in the stadiums (Madalozzo \& Berber Villar, 2009).

This work used some of these factors, as the average income of the city hosting the match, the importance of the match, the proportion of points earned by the teams, the squad value of the home team and visiting team, and the rivalry between the teams (Azevedo et al., 2019). Likewise, the classification of the visiting team and the home team in the championship, the average price of the ticket, and the reputation of the teams are also highlighted in the literature (Gasparetto et al., 2018).

Given the recent report of Datafolha (2018) that indicates a drop in interest in football in Brazil, it is necessary to know in which configurations the fans express greater desire to follow the matches on the spot. Another paper by Gasparetto and Barajas (2020) also points out that the State Championships are the least attractive in terms of the audience in free-to-air TV broadcasts. Therefore, this work aimed to analyze comparatively the matches of the first professional division, divided by Module I and Module II, of the Campeonato Mineiro, the Minas Gerais state championship, seeking to understand in which combinations of factors the public is present in the stadiums.

\section{Method}

Comparative Configurational Methods (CCMs) are a relatively recent approach in the universe of empirical social research, introduced by Charles Ragin in 1987 (Ragin, 2009). First introduced by the Qualitative Comparative Analysis (QCA) CCMs later adopted new approaches such as the Coincidence Analysis (CNA) (Baumgartner, 2009). The CNA is based on INUS conditions (insufficient but non-redundant part of an unnecessary but sufficient condition) taken as the core of so-called regularity theories of causation (Baumgartner \& Falk, 2019; Mackie, 1974).

This analysis detects deterministic causal structures, since general causation can be seen as Boolean dependencies between values of types of event factors. According to the approach, the searched result is at least one solution in Boolean syntax that can be interpreted causally if, and only if, it corresponds to a minimally necessary disjunction of minimally sufficient conjunctions of values of factors for the phenomenon of interest (Baumgartner \& Ambühl, 2018).

Two indicators are important for understanding the results: the degrees of consistency and coverage. Consistency values are the degree to which empirical evidence is consistent with the theoretical relationship of the sets (Rihoux \& Ragin, 2009). Coverage values are evidence of the importance of conditions. A very low coverage value means that there are just a few cases of the outcome covered by the solution (Ragin, 2009). Based on the experiences of Ambühl and Baumgartner (2019), Baumgartner and Epple (2014) and Thiem $(2014,2015)$ it is accepted that the solutions are conceptually consistent and cover a reasonable number of cases if the values of the consistency and coverage indicators are greater than or equal to 0.75 .

Boolean operations and their notations are shown in the table below: 
Table 1. Boolean notation

\begin{tabular}{|l|l|}
\hline AND & $*$ \\
\hline NOT & Lower case \\
\hline OR & + \\
\hline IF, AND IF ONLY & $<->$ \\
\hline
\end{tabular}

Considering the different analysis models, the so-called fuzzy-set analysis is the most granular type of analysis (Ragin, 2009). The challenge of fuzzy logic is to validly transform an original non configurational value into a fuzzy value within the range between [0] and [1]. This process is called calibration, an attribution of scores in the closed unit interval for each of the original values of the variables (Thiem \& Dusa, 2013).

Given the need to understand, in practice, two different competitions, we divided this work into two studies. The first dealing only with data from Module I of the Minas Gerais Championship, and data related to this competition. The second study was worked with data from Module II and its teams. Thus, certain data are different, as they are distinct competition contexts.

In the first of two studies we accessed the game registers of the Module I championships between 2015 and 2018 provided by the Minas Gerais Football Federation (Federação Mineira de Futebol, [s.d.]) totalling 291 matches, and organized the attendance rate, the proportion of points in the championship, and revenues. In sequence, we extracted the squad values from the Transfermarkt's platform and the city's average income data through the government report of Instituto Brasileiro de Geografia e Estatística (IBGE, 2017). All factors used in this study are shown in the table below:

Table 2. Factors used in Study 1

\begin{tabular}{|c|c|}
\hline Factors & Sources \\
\hline Occupancy rate (OCU) & Outcome \\
\hline Classification of the home team (CLAM) & Gasparetto et al. (2018) \\
\hline Classification of the visiting team (CLAM) & (2009) \\
\hline Average ticket (TM) & $\begin{array}{c}\text { Gasparetto et al. (2018); Madalozzo \& Berber Villar } \\
\text { Reputation of the home team (REPM) }\end{array}$ \\
\hline Reputation of the visiting team (REPV) & Gasparetto et al. (2018) \\
\hline Average income of the city hosting the match (RMCID) & Azevedo et al. (2019) \\
\hline Rivalry between the teams (RIV) & ADMKT (2018) \\
\hline Round of competition (RODA) & ADMKT (2018); Gasparetto et al. (2018) \\
\hline Good proportion of points earned by the home team \\
(APM) & ADMKT (2018); Gasparetto et al. (2018) \\
\hline Good proportion of points earned by the visiting team \\
(APV)
\end{tabular}

In this process, we defined maximum, minimum, and threshold points. The set of crossover points was the median of attendance distribution data, the squads' values, the proportion of points earned with respect to the total points awarded, and average city income. The calibration of the factors used the S-shape logarithmic transformation described by Thiem and Dusa (2013) from the definition of the minimum, maximum, and threshold points.

In sequence, for the second study, we accessed the game registers of the Module II championships between 2015 and 2018 totalling 332 matches (Federação Mineira de Futebol, [s.d.]). 
We removed from the sample the matches that resulted in the defeat by Walkover (WO) of one of the teams and that, motivated by punishment, had been held with the gates closed.

Then, data on stadium attendance rates, the proportion of points earned, and game revenues were organized. A factor not yet used at this level of competition in the context of Brazilian football is the distance between the cities of the participating teams (Mayer, 2015), this data was obtained from public sources (IBGE, 2017). Two other factors were used because in other contexts they can be elements of the rivalry combined with the distance factor between cities (Havard, 2017). Such (i) the year of the foundation of the teams; (ii) if there was historical rivalry between the teams. Other data sought from the match records and used to help understand the context of this competition was to indicate whether the game would be played in the host city of the home team. This last data was necessary because, due to the structure of the stadiums, the Federation can determine the realization of the match in a different place that can hold the event. Calibration used the median for these factors in this second study to define the crossover points (Thiem \& Dusa, 2013). All factors used in this study are shown in the table below:

Table 3. Factors used in Study 2

\begin{tabular}{|c|c|}
\hline Factors & Sources \\
\hline Occupancy rate (OCU) & ODAtcome \\
\hline Classification of the home team (CLAM) & Gasparetto et al. (2018) \\
\hline Classification of the visiting team (CLAM) & (2009) \\
\hline Average ticket (TM) & Azevedo et al. (2019) \\
\hline Average income of the city hosting the match (RMCID) & Azevedo et al. (2019) \\
\hline Rivalry between the teams (RIV) & ADMKT (2018) \\
\hline Round of competition (RODA) & ADMKT (2018); Gasparetto et al. (2018) \\
\hline $\begin{array}{c}\text { Good proportion of points earned by the home team } \\
\text { (APM) } \\
\text { (APV) }\end{array}$ & ADMKT (2018); Gasparetto et al. (2018) \\
\hline $\begin{array}{c}\text { Good proportion of points earned by the visiting team } \\
\text { (CINAT) }\end{array}$ & Havard (2017) \\
\hline $\begin{array}{c}\text { The match was held in the home team hometown } \\
\text { Year of the foundation of the home team (FUNM) }\end{array}$ & Havard (2017) \\
\hline Year of the foundation of the visiting team (FUNM) \\
\hline $\begin{array}{c}\text { Distance between the cities of the clubs participating in } \\
\text { the game (DIST) }\end{array}$
\end{tabular}

\section{Results}

\section{Study 1}

We found a solution with parameters of consistency and coverage within the ideal values. We demonstrate the solution in the table below:

Table 4. Found solution

\begin{tabular}{|c|c|c|}
\hline Solution & Consistency & Coverage \\
\hline $\mathrm{CLAV} * \mathrm{tm}+\mathrm{APV} * \mathrm{VELV}+\mathrm{CLAM} * \mathrm{REPV} *$ roda <-> OCU & 0.75 & 0.75 \\
\hline
\end{tabular}

In addition, this solution can be transcribed as follows: 
There is a public presence in the stadium if and only if, the match involves a visiting team with a good position in the league table (CLAV) AND a non-low value of the average ticket (tm) OR, alternatively, the visiting team with a good proportion of points in the championship (APV) AND a high value of the visiting team squad (VELV) OR a good ranking of the home team (CLAM) AND a good reputation from the visiting team (REPV) AND an absence of importance of the round for the championship (roda).

In two of the conjunctions of the solution that point to the cause of the public's presence in the stadiums are present the value of the visiting team and the reputation of the visiting team. This implies the importance of high-ranking teams in attracting an audience to the stadiums for these competitions, leading to a strategy of maintaining these teams in the competition in view of the possible proposal to withdraw them from these tournaments.

When we evaluate the third conjunction, it was possible to perceive the importance of a team with a reputation (in the calibration performed, this factor included teams from the first and second national divisions). This element combined with the good performance of the home team, even in face of the absence of the importance of the round, was a minimally sufficient condition that explained the presence of the public in the stadiums.

\section{Study 2}

The analysis did not find complex causal solutions within the ideal parameters of consistency and coverage proposed by Ambühl and Baumgartner (2019). This result does not preclude observing secondary analyses such as evaluating, for example, the existence of minimally sufficient conditions to cause a good attendance rate in stadiums.

These conditions are recognized in the Regularity Theories as conjunctions of factors that may explain the event of interest, although they do not cover all the possible cases (Baumgartner, 2013). We found four minimally sufficient conditions of maximum consistency. In three of these conditions, there is the presence of the classification factor of the home team (CLAM) AND the absence of the factor that points game town is the same as that of the home team (cinat). These three conditions are in conjunction with a third factor [respectively a low average income of the game city (rmcid), a low average ticket (TM), and a high distance between the cities of the clubs participating in the game (dist)]. The fourth condition shows the presence of a good proportion of points earned by the home team (APM) AND the game town not being the same as that of the home team (cinat) AND absence of importance of the round (roda). See Table 3.

Table 5. Minimally Sufficient Conditions with maximum Consistency

\begin{tabular}{|c|c|c|}
\hline Minimally Sufficient Conditions & Consistency & Coverage \\
\hline CLAM*rmcid*cinat -> OCU & 1 & 0.01559 \\
\hline CLAM*TM*cinat -> OCU & 1 & 0.01400 \\
\hline CLAM*cinat*dist -> OCU & 1 & 0.01066 \\
\hline roda*APM*cinat -> OCU & 1 & 0.00983 \\
\hline
\end{tabular}

The minimally sufficient conditions found with maximum consistency values show the importance of some factors. The absence of the hometown factor, that is, when the match takes place in another city than the host city of the home team, is present in all conjunctions presented. The combination of this element with factors related to the performance of the home team, both the classification of the team in the championship and its proportion of points earned, may suggest a certain attraction of fans who - not necessarily - are loyal supporters of the teams, but only curious 
spectators. Other elements pointed out in the combinations, such as a low average ticket, the low average income of cities, absence of importance of the round, and a great distance between the cities, in which the teams participating in the game are located, seem to compose this characteristic of opportunist spectator. In other words, these combinations seem to point to the presence of an audience attracted by the performance of the home team, who are playing games away from their host city and with some other element that contributes to their presence in the match.

To complement this analysis with minimally sufficient conditions, we reduced the values of the consistency parameter to 0.95 . This action resulted in four other different conditions, which showed the importance of the rivalry (RIV) factor in the cause of a good stadium occupancy rate. Factors related to performance, such as the ranking of the home team in the championship and its proportion of points earned, make up the combinations again. This points to the importance of a competitive team in the presence of the public in the stadiums. Another factor that repeats under these conditions is that which points to an absence of high average incomes in the city. This element may suggest football as a leisure alternative in cities whose average income is low (See Table 4). These conditions serve as support in the study of the analysis to establish criteria for decision-making in relation to the state championships in the future.

Table 6. Minimally Sufficient Conditions with a high level of Consistency

\begin{tabular}{|c|c|c|}
\hline Minimally Sufficient Conditions & Consistency & Coverage \\
\hline CLAM*cinat -> OCU & 0.954 & 0.01575 \\
\hline CLAM*RIV*rmcid -> OCU & 0.969 & 0.09968 \\
\hline RIV*rmcid*APM -> OCU & 0.974 & 0.09252 \\
\hline TM*RIV*rmcid -> OCU & 0.958 & 0.06351 \\
\hline
\end{tabular}

\section{Discussion}

At the beginning of the work, we brought two comments made in the Brazilian press about the need to modify the state championships (Coelho, 2020; Pereira, 2014). Although studies such as Serrano (2018) and Gasparetto et al. (2018) alert to the importance of these competitions in the Brazilian football ecosystem. Part of the press argues that the most reputable teams should no longer compete in these championships.

The results we found in the first study refute these arguments, supporting the importance of the participation of the most reputable teams and with squads that are more valuable in explaining the presence of the fans in the stadiums.

In fact, the result of Study 1 makes these teams necessary elements for attracting audiences in the championships. What is exposed in the result found is that the relevance and value of the squad are necessary for visiting teams, this requires thinking about more games of these big clubs in the inner cities of the state, exactly where they are visitors.

A proposal arising from this finding could transform the competition so that it adopts regional headquarters in which big squads can face smaller teams as visitors, within groups of four to six clubs, without having to make large displacements. This solution could reduce the number of total games played by the big teams and serve as events to attract local audiences in a shorter amount of time.

Study 2, aimed at understanding a competition that has no large teams in Brazilian football, found minimally sufficient conditions to explain the presence of the public. These minimally sufficient conditions found in the second study denote the relationship between the performances of the home team in motivating the fans to follow the club in the stadium. This relationship between 
performance and presence of the public had already been detected in studies brought here as a theoretical basis, such as ADMKT (2018), Madalozzo and Berber Villar (2009), and Fagundes et al. (2013).

In addition, it was possible to note interesting factors in the minimally sufficient conditions, such as rivalry and the fact that the game with the public was held in a city other than the host city of the home club. One option to explore these elements might be to hold regional conferences, as often happens in United States of America sports, as a way to involve more games between rival teams, with playoff matches in previously predetermined cities.

Although this work brings new information about a lower-important football competition and expands on the findings of Silveira and Melo (2018) about the clubs that dispute the lowest echelons of professional football in Brazil. This work becomes relevant because it addresses a scenario that covers most professional clubs in this country and distant from the eyes of the great public fan of the sport.

\section{Conclusions and recommendations}

This research found a combination of factors using Coincidence Analysis to point out the cause of the presence of the public in stadiums to watch Module I of the Minas Gerais Soccer Championship. It also found minimally sufficient conditions to explain the event when analyzing the publics of Module II of the state championship. Decision-makers to wish the reformulation of these tournaments in the future can use the solutions pointed out in this study to attract the audience to the arenas.

A limitation of the present work is related to the limited amount of data to assign the market value to the competing teams, both in Module I and Module II. The solution found for the first study was to use data from the Transfermarkt platform (transfermarkt.de) although the validation of these data is discussed in academia. The second study about Module II did not find any possible source to measure the market value of the athletes and, consequently, the total value of the team.

The use of methodological approaches such as Coincidence Analysis adds to the studies of applied social sciences, mainly to the study of the economic and market aspects of sports management. We encourage its use by new researchers for the emergence of new perspectives on the topics discussed in these areas.

We suggest new studies using the CNA, adding new factors whose interaction with those that integrate this work can bring different solutions. It is also possible to carry out this work with data from other state championships of similar structure, such as the states of Rio de Janeiro, São Paulo, Bahia, and the Rio Grande do Sul. These other scenarios can bring different causal relationships between the factors.

Some factors can be added or modified within the main analysis of this study. One possibility would be to change the value of the squad by a factor that includes high-profile players (e.g. athletes from the National Football Team). Other factors that can be added to the analysis are related to the structure of the stadium, such as the comfort of the seats (or bleachers), accessibility, presence of snack bars, and cleanliness of the restrooms.

A suggestion for future investigations is the deepening of the relationship between the performance of the teams and the presence of the public in the football stadiums. It is also suggested to investigate the relevance of rivalry as a stimulating element for the public's presence. Finally, the 
detection of stadium occupation occurring in low-income cities points to the need for a more detailed understanding of this relationship.

Finally, yet importantly, we emphasize that this paper discusses the state championships. This is the base of the Brazilian football ecosystem and received criticism for its current format. It is necessary to warn about the number of professionals involved in this kind of competition, since eliminating them can drastically affect the structure of football in Brazil.

\section{Referências}

ADMKT. (2018). Relatório de presença de público nos estádios brasileiros 2012-2017 (Relatório Técnico Relatório de pesquisa vinculado ao Projeto de Extensão PJ354-2017 da UFG; p. 37). Universidade Federal de Goiás

Ambühl, M., \& Baumgartner, M. (2019). cnaOpt: Optimizing Consistency and Coverage in Configurational Causal Modeling (0.1.1) [Computer software]. https://CRAN.Rproject.org/package $=\mathrm{cnaOpt}$

Azevedo, L., Marchioro, L., \& Troyner, L. R. (2019, agosto 27). País do futebol? A porcentagem de ocupação nos estádios e a sua variabilidade no Campeonato Brasileiro 2018. Anais do V Encontro de Economia da UEPG. V Encontro de Economia da UEPG, Ponta Grossa.

Baumgartner, M. (2009). Inferring Causal Complexity. Sociological Methods \& Research, 38(1), 71-101. https://doi.org/10.1177/0049124109339369

Baumgartner, M. (2013). Detecting Causal Chains in Small-n Data. Field Methods, 25(1), 3-24. https://doi.org/10.1177/1525822X12462527

Baumgartner, M., \& Ambühl, M. (2018). Causal modeling with multi-value and fuzzy-set Coincidence Analysis. Political Science Research and Methods, X, 1-17. https://doi.org/10.1017/psrm.2018.45

Baumgartner, M., \& Epple, R. (2014). A Coincidence Analysis of a Causal Chain: The Swiss Minaret Vote. Sociological Methods \& Research, 43(2), 280-312. https://doi.org/10.1177/0049124113502948

Baumgartner, M., \& Falk, C. (2019). Boolean Difference-Making: A Modern Regularity Theory of Causation. The British Journal for the Philosophy of Science. https://doi.org/10.1093/bjps/axz047

CBF. (2019). Impacto do Futebol Brasileiro (No 1; p. 73). Confederação Brasileira de Futebol.

Coelho, P. V. (2020, julho 2). "Os campeonatos estaduais como a gente conhece acabaram hoje". Uol Esportes. https://www.uol.com.br/esporte/futebol/ultim as-noticias/2020/07/02/os-campeonatos- estaduais-como-a-gente-conhece-acabaramhoje-diz-pvc.htm

Datafolha, I. (2018). Futebol e Copa do Mundo (Pesquisa de Opinião No PO813950). Instituto Datafolha.

http://datafolha.folha.uol.com.br/opiniaopubli ca/2018/04/1964748-flamengo-e-corinthiansseguem-na-lideranca-de-torcidas.shtml

Fagundes, A. F. A., Veiga, R. T., Sampaio, D. de O., Sousa, C. V. e, Santana, É. E. de P., \& Lara, J. E. (2013). Um estudo sobre a satisfação do consumidor esportivo que frequenta estádios de futebol em Belo Horizonte. Revista Eletrônica de Ciência Administrativa (RECADM), 12(1), 121-135. https://doi.org/10.5329/RECADM.2013004

Federação Mineira de Futebol. ([s.d.]). Campeonato Mineiro Módulo I. Competições. Recuperado 6 de agosto de 2020, de http://fmf.com.br/Competicoes/ProxJogos.as $\mathrm{px} ? \mathrm{~d}=1$

Gasparetto, T., \& Barajas, A. (2020). The Role of Tournament Relevance for Football Matches on Free-to-Air Television. International Journal of Sport Finance, 15(1), 16-27. https://doi.org/10.32731/IJSF/151.022020.02

Gasparetto, T., Barajas, A., \& Fernandez-Jardon, C. M. (2018). Brand teams and distribution of wealth in Brazilian State Championships. Sport, Business and Management: An International Journal, 8(1), 2-14. https://doi.org/10.1108/SBM-03-2017-0016

Havard, C. T. (2017). Rivalry: How it impacts fans, teams, and sport managers. www.SportRivalry.com

IBGE. (2017, outubro 5). Sistema agregador de informações do IBGE sobre os municípios e estados do Brasil. [Governamental]. Portal das Cidades. https://cidades.ibge.gov.br/

Mackie, J. L. (1974). The Cement of the Universe: A Study of Causation. Clarendon Press.

Madalozzo, R., \& Berber Villar, R. (2009). Brazilian Football: What Brings Fans to the Game? Journal of Sports Economics, 10(6), 639-650. https://doi.org/10.1177/1527002509335572

Mayer, K. (2015). Attendance motivators and constraints: An investigation of students at the 
Football Championship Series division [Thesis, University of Northern Colorado]. https://digscholarship.unco.edu/dissertations/ 38

Penn, M. (2019, março 30). “Arsenal reach verbal agreement with Gabriel Martinelli... one thing is delaying announcement" [News]. Express.

https://www.express.co.uk/sport/football/110 7467/Arsenal-transfer-news-GabrielMartinelli-Unai-Emery-Yannick-Carrasco

Pereira, M. C. (2014, março 23). "Não defendo o fim dos Estaduais, mas sua total reformulação" [Rede Social]. Twitter. https://twitter.com/maurocezar/status/447879 239300567040

Ragin, C. C. (2009). Redesigning Social Inquiry: Fuzzy Sets and Beyond. University of Chicago Press.

Rihoux, B., \& Ragin, C. C. (2009). Configurational Comparative Methods: Qualitative Comparative Analysis (QCA) and Related Techniques. SAGE.

Rocha, C. M., \& Fleury, F. A. (2017). Attendance of Brazilian soccer games: The role of constraints and team identification. European Sport Management Quarterly, 17(4), 485505. https://doi.org/10.1080/16184742.2017.1306 871

Serrano, R. (2018). Ecossistema produtivo do esporte: Modelagem e análise sistêmica a partir do futebol brasileiro [Tese de Doutorado]. Universidade do Vale do Rio dos Sinos.

Silveira, H. D. da, \& Melo, E. de L. (2018). Captação de recursos nos clubes de terceira divisão do futebol cearense em 2017. Revista de Gestão e Negócios do Esporte, 3(1), 115126.

Thiem, A. (2014). Navigating the Complexities of Qualitative Comparative Analysis: Case Numbers, Necessity Relations, and Model Ambiguities. Evaluation Review, 38(6), 487513.

https://doi.org/10.1177/0193841X14550863

Thiem, A. (2015). Using Qualitative Comparative Analysis for Identifying Causal Chains in Configurational Data: A Methodological Commentary on Baumgartner and Epple (2014). Sociological Methods \& Research, 44(4), 723-736. https://doi.org/10.1177/0049124115589032

Thiem, A., \& Dusa, A. (2013). Qualitative Comparative Analysis with R: A User's Guide. Springer-Verlag.
Recebido em: 04/08/2021

Aceite em: 28/09/2021

Endereço para correspondência:

Felipe Alexandre de Souza Félix Nunes fasfn@adm.mest.ufmg.br

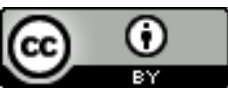

Esta obra está licenciada sob uma Licença Creative Commons Attribution 3.0 